\title{
9. A különleges jogrend alkotmányos és törvényi szintú szabályozása Csehországban
}

\author{
HOJNYÁK DÁVID-SZINEK CSÜTÖRTÖKI HAJNALKA
}

\section{A különleges jogrend alkotmányos és törvényi szintü szabályozása}

A különleges jogrendre vonatkozó szabályozás a cseh jogrendben kizárólag alkotmányos szinten jelenik meg. A cseh alkotmányos szabályozás a hadiállapoton kívül eredetileg nem tartalmazott a különleges jogrendre vonatkozó rendelkezéseket, azonban az 1998-ban elfogadott, a cseh állam biztonságáról szóló alkotmánytörvény pótolta az alkotmányos szabályozás e hiányosságát. Az Állambiztonsági alk.tv. a különleges jogrendi tényállások taxatív felsorolását és átfogó szabályozását adja. A különleges jogrendre vonatkozó alapvetô szabályok mellett ugyanakkor ismertetésre kerülnek a különleges jogrendet megelőző, az arra való felkészülést szolgáló békeidejú szabályok, valamint a válságkezeléssel kapcsolatos jogi rendelkezések is.

1 Ústavní zákon č. 110/1998 Sb., o bezpečnosti České republiky (a továbbiakban:Állambiztonsági alk.tv.).

Dr. Hojnyák Dávid

david.hojnyak@mfi.gov.hu

kutató (Mádl Ferenc Összehasonlító Jogi Intézet)

PhD-hallgató (Miskolci Egyetem Deák Ferenc Állam- és Jogtudományi Doktori Iskola)

Dr. Szinek Csütörtöki Hajnalka

kutató (Mádl Ferenc Összehasonlító Jogi Intézet)

PhD-hallgató (Miskolci Egyetem, Deák Ferenc Állam- és Jogtudományi Doktori Iskola)

Hojnyák, D., Szinek Csütörtöki H. (2021) 'A különleges jogrend alkotmányos és törvényi szintû szabályozása Csehországban' in Nagy, Z., Horváth, A. (szerk.) A különleges jogrend és nemzeti szabályozási modelljei, 217-240. o. Budapest: Mádl Ferenc Összehasonlító Jogi Intézet.

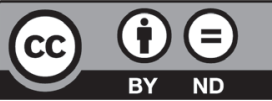


A cseh jogrend kapcsán ugyanakkor fontos megjegyezni, hogy a cseh alkotmány értelmében az alkotmánytörvények ${ }^{2}$ (más néven: alkotmányos törvények vagy alkotmányerejû́ törvények) a Cseh Köztársaság Alkotmányával, valamint az Alapjogok és Alapvető Szabadságok Chartájával együtt alkotják a Cseh Köztársaság alkotmányos rendjét. ${ }^{3} \mathrm{Az}$ alkotmány e rendelkezése alapján az alkotmánytörvények - így a fentebb említett Állambiztonsági alk. tv. is - a cseh alkotmányos rend részét képezik, így az ilyen jogszabályban foglaltak alkotmányos szintú szabályozásnak minősülnek. Míg a különleges jogrendre vonatkozó általános szabályok a cseh jogrendben alkotmányos szinten találhatók meg, addig a különleges jogrendet megelőző, az arra való felkészülést szolgáló békeidejú szabályok, valamint a válságkezelésre vonatkozó szabályok törvényi szinten kerültek rögzítésre.

A cseh jogrendben a különleges jogrend nevesített esetkörei a következők: szükségállapot (nouzový stav), ${ }^{4}$ államot fenyegető állapot (stav ohrožení státu) ${ }^{5}$ és hadiállapot (válečný stav). ${ }^{6}$

Az Állambiztonsági alk.tv. értelmében szükségállapot elrendelésére akkor van lehetőség, ha természeti, ökológiai vagy ipari katasztrófa, baleset vagy egyéb veszély következett be, amely az életet, az egészséget, a vagyonbiztonságot, a közrendet vagy a közbiztonságot jelentős mértékben veszélyezteti.7 Mint látható, ez a meghatározás nyitott, mivel tartalmazza az „egyéb veszély” kifejezést is. A kihirdetés konkrét okának nem kell egybeesnie az elôre rögzített események egyikével, azonban összehasonlíthatónak kell lennie a védett érték veszélyeztetésének alkalmasságával. ${ }^{8}$

Szükségállapot az ország egész területére, valamint annak egyes, meghatározott részei tekintetében is elrendelhetô. ${ }^{9}$ Szükségállapot esetén a kormány dönt annak elrendeléséről, azonban a kormánynak a kétkamarás törvényhozó hatalom ${ }^{10}$ alsóházát, a képviselőházat erről haladéktalanul tájékoztatnia kell, amely e döntést megsemmisítheti. ${ }^{11}$ Figyelni kell azonban arra, hogy az alkotmánytörvény szabályozása alapján a szükségállapot kihirdetésével egyidejúleg a kormány köteles meghatározni, hogy mely, külön törvényben lefektetett jogok

$2 \mathrm{Az}$ alkotmánytörvények elfogadásához az összes képviselő háromötödös többségének (minősített többség), valamint a jelen lévő szenátorok háromötödös többségének jóváhagyása szükséges [Cseh Köztársaság Alkotmánya (a továbbiakban: alkotmány) 39. cikk (4) bekezdés].

3 Alkotmány 112. cikk (1) bekezdés.

4 Az Állambiztonsági alk.tv. a nouzový stav kifejezést, míg az alkotmánytörvény hivatalos angol nyelvủ fordítása a state of emergency kifejezést használja.

5 Az Állambiztonsági alk.tv. a stav ohrožení státu kifejezést, míg az alkotmánytörvény hivatalos angol nyelvủ fordítása a condition of threat to the state kifejezést használja.

6 Az Állambiztonsági alk.tv. a válečný stav kifejezést, míg az alkotmánytörvény hivatalos angol nyelvú fordítása a state of war kifejezést használja.

7 Állambiztonsági alk.tv. 5. cikk (1) bekezdés.

8 A téma kapcsán lásd bővebben: Rychetský et al., 2015.

9 Állambiztonsági alk.tv. 2. cikk (2) bekezdés.

10 A cseh törvényhozó hatalom, a parlament kétkamarás, amelynek alsóháza a 200 főből álló képviselőház, felsőháza pedig a 81 szenátorból álló szenátus.

11 Állambiztonsági alk.tv. 5. cikk (4) bekezdés 
és milyen mértékben kerülnek korlátozásra. ${ }^{12}$ Minderre azonban kizárólag az Alapjogok és Alapvetô Szabadságok Chartájával összhangban kerülhet sor, amely rögzíti az alapvető jogok és szabadságok korlátozhatóságának szabályait. Emellett a kormánynak meg kell határoznia azt is, hogy milyen kötelezettségeket és milyen mértékben ír elö. ${ }^{13} \mathrm{~A}$ szükségállapot legfeljebb 30 napig tarthat, amely azonban meghosszabbítható a képviselőház előzetes hozzájárulásával. ${ }^{14}$ Ugyanakkor a kormány vagy a képviselőház dönthet úgy is, hogy a meghatározott időtartam lejártát megelőzően megszünteti a szükségállapotot..$^{15}$ Fontos szabályként rögzíti továbbá az alkotmánytörvény, hogy szükségállapot nem rendelhető el olyan sztrájk esetében, amely jogok védelme vagy jogos gazdasági és társadalmi érdek védelme céljából szerveződött. ${ }^{16}$

E ponton rögzítendő, hogy a szükségállapot egy speciális, gyorsított eljárási formájának tekinthető a közvetlen veszélyhelyzet, amikor is a miniszterelnök maga rendelheti el a szükségállapotot, amennyiben a késedelem veszéllyel járna. A miniszterelnök intézkedését azonban 24 órán belül a kormánynak jóvá kell hagynia vagy meg kell semmisítenie. ${ }^{17}$ Erre az esetre is érvényes ugyanakkor az a szabály, hogy a képviselőház e döntést utólagosan megsemmisítheti.

Az alkotmánytörvény szabályozása alapján az államot fenyegetőállapot akkor rendelhető el, ha az állam szuverenitását, területi integritását vagy demokratikus alapjait külső hatalom közvetlenül fenyegeti ${ }^{18} \mathrm{~A}$ szükségállapottal ellentétben az államot fenyegető állapotnál a fenyegetés demonstratív felsorolása hiányzik, csak a "védelem tárgya” került szabályozásra. ${ }^{19}$ Az államot fenyegető állapot szabályozása kapcsán azonban hiányzik az alapjogok korlátozására-korlátozhatóságára való utalás. Ezzel kapcsolatban megjegyzendő, hogy a cseh alkotmányjogi szakirodalomban megjelenik olyan álláspont, amely az Állambiztonsági alk.tv. rendelkezéseit ${ }^{20}$ úgy értelmezi, hogy azok polgári kötelezettséget keletkeztetnek. Ez alapján az állampolgároknak részt kell venniük az állam biztonságának biztosításában, ami felfogható az alapvető jogokba való beavatkozás tolerálásának kötelezettségeként. ${ }^{21}$ E jogszabályi rendelkezés ilyen módon való értelmezése minden bizonnyal lehetséges, kérdéses azonban, hogy miért a legenyhébb különleges jogrendi tényállás, a fentebb ismertetett

12 Sládeček, 2020, 273. o.

13 Állambiztonsági alk.tv. 6. cikk (1) bekezdés. E jogszabályhely kapcsán ugyanakkor megjegyzendő, hogy a cseh szövegben rögzített zvláštní zákon kifejezés és az angol nyelvú fordításban megjelenő individual statutes kifejezés nem teljesen fedi egymást. Jelen munkában, a cseh szövegben rögzített kifejezést alapul véve a külön törvény kifejezést tekintjük irányadónak.

14 Állambiztonsági alk.tv. 6. cikk (2) bekezdés.

15 Állambiztonsági alk.tv. 6. cikk (3) bekezdés.

16 Állambiztonsági alk.tv. 5. cikk (2) bekezdés.

17 Állambiztonsági alk.tv. 5. cikk (3) bekezdés.

18 Állambiztonsági alk.tv. 7. cikk (1) bekezdés.

19 Lásd bővebben: Pavlíček et al., 2011.

20 Állambiztonsági alk.tv. 3. cikk (2) bekezdés.

21 Vaníček, 2001, 264. o. 
szükségállapot esetében tartalmaz a jogszabály kifejezett felhatalmazást az alapvető jogok korlátozása kapcsán. ${ }^{22}$

Az államot fenyegetô állapot a kormány indítványára kizárólag a képviselóház, valamint a szenátus abszolút többségének támogatása mellett rendelhetô el. ${ }^{23} \mathrm{Az}$ államot fenyegető állapot a szükségállapothoz hasonlóan az ország egész területére, valamint annak meghatározott részei tekintetében egyaránt elrendelhetô. ${ }^{24} \mathrm{Az}$ államot fenyegetó állapot idején a kormány kezdeményezheti, hogy a parlament sürgős eljárásban tárgyalja az általa benyújtott törvényjavaslatokat. A képviselőháznak az ilyen törvényjavaslatokról a benyújtástól számított 72 órán belül határoznia kell, majd azt a szenátusnak továbbítja, amely köteles a felterjesztéstôl számított 24 órán belül határozni a törvényjavaslatról. Amennyiben a szenátus ez idő alatt nem nyilvánít véleményt a törvényjavaslatról, akkor azt elfogadottnak kell tekinteni. ${ }^{25} \mathrm{Az}$ államot fenyegető állapot idején nem illeti meg a köztársasági elnököt az elfogadott törvények visszaküldésének joga (vétójog) az olyan törvények vonatkozásában, amelyeket sürgős eljárásban fogadott el a parlament. ${ }^{26} \mathrm{~A}$ kormány esetében pedig korlátként jelenik meg, hogy alkotmánytörvény megalkotására irányuló törvényjavaslatot nem kezdeményezhet sürgős eljárásban. ${ }^{27}$ Kiemelendő, hogy az alkotmánytörvény hallgat arról, hogy miként lehet az államot fenyegetó állapotot megszüntetni, kivételt jelent ez alól az az eset, ha a bejelentés konkrét határidőt tartalmaz. Az erre jogosult valószínúsíthetően az államot fenyegető állapotot kihirdetô állami szerv, tehát a parlament lesz. ${ }^{28}$

A hadiállapottal kapcsolatos szabályok részben az alkotmányban, részben az alkotmánytörvényben kerültek rögzítésre. A hadiállapot kinyilvánításáról a parlament határozhat, amennyiben a Cseh Köztársaságot megtámadják, vagy nemzetközi szerződés közös védelmi kötelezettséget ír elő az ország számára. ${ }^{29} \mathrm{~A}$ hadiállapot kinyilvánításáról szóló határozat elfogadásához a képviselők, valamint a szenátorok többségének szavazata szükséges. ${ }^{30}$ A cseh szabályozás hiányossága figyelhető meg ugyanakkor a tekintetben, hogy sem az alkotmány, sem az alkotmánytörvény nem határozza meg, hogy ki(k) vagy mely szerv(ek) kezdeményezhetik a hadiállapot elrendelését. Az alkotmánytörvény értelmében hadiállapot kizárólag az ország egész területére rendelhető el, ellentétben a már elemzett szükségállapot, valamint az államot fenyegető állapot kategóriákkal, amely tényállások kapcsán azt látjuk, hogy az ország egyes, meghatározott részei tekintetében is elrendelhetók. ${ }^{31} \mathrm{Az}$ alkotmánytörvény megfogalmazásából a hadiállapot ultima ratio jellegére következtethetünk, hiszen

22 Klíma, 2009, 877. o.

23 Állambiztonsági alk.tv. 7. cikk (1)-(2) bekezdés.

24 Állambiztonsági alk.tv. 2. cikk (2) bekezdés.

25 Állambiztonsági alk.tv. 8. cikk (1)-(2) bekezdés.

26 Állambiztonsági alk.tv. 8. cikk (3) bekezdés.

27 Állambiztonsági alk.tv. 8. cikk (4) bekezdés.

28 Stejskal, 2017, 34. 0.

29 Alkotmány 43. cikk (1) bekezdés.

30 Alkotmány 39. cikk (3) bekezdés.

31 Állambiztonsági alk.tv. 2. cikk (2) bekezdés. 
hadiállapot elrendelésére csak akkor van lehetőség, ha kevésbé intenzív intézkedések - tehát a szükségállapot vagy az államot fenyegető állapot elrendelése - nem megfelelőek vagy elégségesek a kívánt cél eléréséhez. ${ }^{32} \mathrm{~A}$ kormány az államot fenyegető állapot szabályaihoz hasonlóan a hadiállapot idején is kezdeményezheti, hogy a parlament sürgős eljárásban tárgyalja az általa benyújtott törvényjavaslatokat, míg a köztársasági elnököt ez esetben sem illeti meg az elfogadott törvények visszaküldésének joga az olyan törvények vonatkozásában, amelyeket sürgős eljárásban fogadott el a parlament.

\subsection{A különleges jogrendi tényállásokra vonatkozó közös szabályok}

Az Állambiztonsági alk.tv. rögzíti, hogy ha a fentebb említett három különleges jogrendi tényállás bármelyikének fennállása esetén az országban uralkodó körülmények nem teszik lehetővé a választások megtartását a rendes választási ciklusra előírt határidőn belül, e határidő törvény által legfeljebb 6 hónappal meghosszabbítható. ${ }^{33} \mathrm{Az}$ alkotmánytörvény továbbá rögzíti, hogy a képviselőház feloszlatása esetén a szenátus illetékes határozni a szükségállapot meghosszabbításáról vagy megszüntetéséról; a hadiállapot, valamint az államot fenyegető állapot kihirdetéséről, illetve dönteni Csehország részvételéről olyan nemzetközi szervezet védelmi rendszerében, amelynek az ország a tagja. ${ }^{34}$ Fontos szabályként jelenik meg továbbá, hogy mindhárom különleges jogrendi tényállás kihirdetéséről szóló határozatot a tömegtájékoztatás útján nyilvánosságra kell hozni, és a törvényekhez hasonlóan ki kell azokat hirdetni. ${ }^{35}$

Összességében elmondható, hogy az Állambiztonsági alk.tv. által rögzített szükségállapot, valamint az államot fenyegetô állapot esetében mindig a kormány kerül felhatalmazásra a szükséges intézkedések kidolgozására. ${ }^{36} \mathrm{Az}$ alkotmánytörvényben továbbá megjelenik a Nemzeti Biztonsági Tanács. ${ }^{37}$ Az NBT alapokmánya értelmében a testület 9 tagú, elnöke a miniszterelnök, míg alelnökei az első számú miniszterelnök-helyettes, valamint a belügyminiszter. ${ }^{38} \mathrm{Az}$ NBT tagja továbbá a védelmi miniszter, a külügyminiszter, a pénzügyminiszter, az ipari és kereskedelmi miniszter, a közlekedési miniszter, az egészségügyi

32 Állambiztonsági alk.tv. 2. cikk (1) bekezdés.

33 Állambiztonsági alk.tv. 10. cikk.

34 Állambiztonsági alk.tv. 11. cikk.

35 Állambiztonsági alk.tv. 12. cikk.

36 Állambiztonsági alk.tv. 5. és 7. cikk.

37 Bezpečnostní Rada Státu (a továbbiakban: NBT). Az NBT múködésével kapcsolatos részletszabályokat a testület alapokmánya rögzíti, amelyet az 544/2014. kormányhatározat (Usnesení vlády ČR ze dne 9. července 2014 č. 544) 1. számú melléklete tartalmaz. E kormányhatározat és a hozzá kapcsolódó melléklet - tehát maga az alapokmány - az utóbbi években többször is módosításra került, legutóbb a 692/2018. kormányhatározat által. A továbbiakban - az egyszerüség kedvéért - az NBT alapokmánya elnevezés alatt kerülnek hivatkozásra a kormányhatározat mellékletében rögzítettek.

38 NBT alapokmánya 3. cikk (1)-(3) bekezdés. E ponton megjegyzendő, hogy a jelenlegi cseh kormány első számú miniszterelnök-helyettese, valamint az ország belügyminisztere ugyanaz a személy, így a gyakorlatban az NBT elnöke, Andrej Babiš kormányfő munkáját alelnökként egy személy, a belügyi tárcát és az első számú miniszterelnöki pozíciót is betöltő Jan Hamáček látja el. 
miniszter, valamint a mezőgazdasági miniszter. ${ }^{39}$ Az NBT meghívására az üléseken jelen lehet a cseh törvényhozás alsóházának (képviselőház), valamint felsőházának (szenátus) elnöke, az NBT-ben nem állandó tag miniszter, valamint más közigazgatási hatóságok vezetôi, helyi és regionális önkormányzatok képviselői, illetve szakértők. ${ }^{40} \mathrm{E}$ szerv feladata a kormány által meghatározott mindazon javaslat elkészítése, amely az állam védelme érdekében szükséges. E rendelkezés kapcsán rögzíti az alkotmánytörvény, hogy a köztársasági elnöknek joga van részt venni az NBT ülésein; az NBT-től vagy annak tagjaitól jelentést kérni, valamint a döntéshozatali hatáskörébe tartozó bármely kérdést megvitatni e szervvel vagy annak tagjaival. ${ }^{41}$ Habár a köztársasági elnök az NBT vonatkozásában pluszjogosítványokat kap, alapvetően az államfő semleges, neutrális szerepköre figyelhető meg a különleges jogrendi tényállások tekintetében. A köztársasági elnök ugyan a fegyveres erők főparancsnoka, valamint kinevezi és előlépteti a tábornokokat, azonban a miniszterelnök vagy az általa megbízott kormánytag ellenjegyzése szükséges a határozatainak érvényességéhez. ${ }^{42}$

Azt látjuk tehát, hogy a különleges jogrendi kormányzás felhatalmazottja szükségállapot, valamint az államot fenyegető állapot esetén a kormány. A hadiállapot tekintetében pedig mind az alkotmány, mind az alkotmánytörvény hallgat arról, hogy ki vagy mely szerv jogosult a kormányzásra. ${ }^{43}$

\subsection{A veszélyhelyzet mint különleges jogrendnek nem minősülő rendkívülifelhatalmazás esetköre}

A klasszikus értelemben vett és fentebb elemzett különleges jogrendi tényállások mellett a cseh jogi szabályozásban megjelenik a veszélyhelyzet (stav nebezpečí) ${ }^{44}$ kategóriája is, amelyet a válságkezelésről szóló törvény ${ }^{45}$ nevesít. Fontosnak tartjuk azonban rögzíteni, hogy egyes szakirodalmi források a veszélyhelyzetet a különleges jogrendi esetkörök negyedik típusaként tartják számon. Ezt a megállapítást e szerzők egyrészt azzal indokolják, hogy az alkotmányos szabályozás a hadiállapot és az államot fenyegető állapot esetén meglehetősen hiányos vagy éppen nem egyértelmú, másrészt pedig az alkotmányos szabályozást nem tekintik kizárólagosnak e témakör vonatkozásában. ${ }^{46}$ Minderre tekintettel e ponton indokoltnak tartjuk rö-

39 NBT alapokmánya 3. cikk (4) bekezdés.

40 NBT alapokmánya 9. cikk (2) bekezdés.

41 Állambiztonsági alk.tv. 9. cikk.

42 Alkotmány 63. cikk (1) bekezdés c) és g) pont, valamint (3) bekezdés.

43 A cseh különleges jogrendi szabályozás kapcsán lásd még: Mareš-Novák, 2019; Kelemen, 2019, 9-35. o.; Kelemen, 2020, 207-234. o.; Jog-összehasonlító módszerrel elemzi az egyes európai országok különleges jogrendi szabályozását: Khakee, 2009, 32-40. 0.

44 A Válságkezelési tv. a stav nebezpečí kifejezést, míg e törvény hivatalos angol nyelvú fordítása a state of danger kifejezést használja.

45 Zákon č. 240/2000 Sb., o krizovém řízení a o změně některých zákonů (a továbbiakban: Válságkezelési tv.). 46 Ennek kapcsán lásd: Kudrna, 2017, 163. o. 
viden ismertetni ezt a kategóriát is, ugyanakkor jelen munka szerzői az alkotmánytörvény hármas felosztását tekintik irányadónak a különleges jogrend esetkörei kapcsán.

Veszélyhelyzetet sürgős intézkedésként akkor lehet elrendelni, ha az emberek élete, egészsége, vagyona, valamint a természeti környezet veszélyben van, azonban a fenyegetés intenzitása nem jelentős mértékú, és a közigazgatási hatóságoknak, a regionális és önkormányzati hatóságoknak, valamint az integrált mentőrendszer egységeinek a szokásos tevékenysége által nem hárítható el az adott fenyegetés. ${ }^{47}$ Veszélyhelyzet egy régión ${ }^{48}$ egész területére vagy annak egy meghatározott részére rendelhető el a regionális kormányzók, míg a fôváros, Prága esetében a főpolgármester által (a továbbiakban együtt: regionális kormányzók). A regionális kormányzóknak a veszélyhelyzet kihirdetését követően haladéktalanul tájékoztatniuk kell a kormányt, a Belügyminisztériumot, a szomszédos régiókat, illetve mindazon régiót, amelyre az adott fenyegetés hatással lehet. ${ }^{49} \mathrm{~A}$ veszélyhelyzet legfeljebb 30 napra rendelhető el, azonban a regionális kormányzók a kormány hozzájárulásával a veszélyhelyzet időtartamát meghosszabbíthatják. ${ }^{50} \mathrm{~A}$ veszélyhelyzetet kihirdetô határozatban rögzíteni kell a veszély elhárításához szükséges válságintézkedéseket, valamint azok hatályátt. ${ }^{51}$ Fontos szabályként rögzíti a törvény, hogy amennyiben nem lehetséges a veszély elhárítása, a regionális kormányzó haladéktalanul felkéri a kormányt, hogy hirdesse ki a szükségállapotot - mint különleges jogrendet - a már korábban rögzített szabályoknak megfelelően. A regionális biztosok által elrendelt válságintézkedések a szükségállapot kihirdetésének napján hatályukat vesztik, kivéve, ha a kormány másként határoz, ugyanakkor a hatályban maradt válságintézkedéseket a kormány intézkedéseinek kell tekinteni. ${ }^{52} \mathrm{~A}$ regionális kormányzó vagy a kormány dönthet úgy, hogy a meghatározott időtartam lejártát megelőzően megszünteti a veszélyhelyzetet, azonban a kormány akkor is megszüntetheti a veszélyhelyzetet, ha az ilyen állapotot kihirdető határozatban foglalt feltételek nem teljesülnek. ${ }^{53}$

\subsection{A különleges jogrendre való felkészülést segitô békeidejü szabályok, valamint a válságkezelésre vonatkozó szabályok}

Míg a különleges jogrendre vonatkozó alapvetô szabályok a cseh jogrendben alkotmányos szinten, a Cseh Köztársaság alkotmányában, valamint az Állambiztonsági alk. tv.-ben találhatók meg, addig a különleges jogrendet megelőző, az arra való felkészülést szolgáló békeidejú szabályok törvényi szinten kerültek rögzítésre. A téma szempontjából elsősorban az alábbi két törvény bír relevanciával: Csehország védelmének biztosításáról szóló

47 Válságkezelési tv. 3. \$(1) bekezdés.

48 Csehország közigazgatásilag 13 régióra és a fôvárosra, Prágára tagolódik.

49 Válságkezelési tv. 3. \$(3) bekezdés.

50 Válságkezelési tv. 3. \$ (4) bekezdés.

51 Válságkezelési tv. 3. \$(2) bekezdés.

52 Válságkezelési tv. 3. $\$(5)$ bekezdés.

53 Válságkezelési tv. 3. \$ (8) bekezdés. 
222/1999. törvény, ${ }^{54}$ valamint a Válságkezelési tv. Lényeges különbséget tenni a két törvény tárgyi hatálya között, hiszen míg az előbbi törvény a korábban rögzített különleges jogrendi tényállások közül az államot fenyegetô állapottal, valamint a hadiállapottal foglalkozik, addig a Válságkezelési tv. e két kategórián kívül eső különleges jogrendi esetkörökkel kapcsolatos szabályokat rögzít..$^{55}$ Mindkét törvény rendelkezik arról, hogy a különleges jogrendre való felkészülés tekintetében az egyes állami és önkormányzati szerveket milyen jogok illetik meg és milyen kötelezettségek terhelik.

A Védelmi tv. elsődlegesen a kormány hatáskörébe utalja a különleges jogrendre való felkészüléssel kapcsolatos feladatokat. ${ }^{56} \mathrm{~A}$ törvény szabályozása konzekvens a tekintetben, hogy kettéválasztja a kormánynak békeidőben, valamint a hadiállapot és az államot fenyegető állapot elrendelése esetén ellátandó feladatait. Ez alapján a kormány békeidőben különösen az alábbi, a különleges jogrendre való felkészülést szolgáló intézkedések megtételére jogosult, valamint kötelezett: ${ }^{57}$

- felméri azokat a kockázatokat, amelyek fegyveres konfliktusok okai lehetnek, és meghozza a szükséges döntéseket az ilyen kockázatok csökkentése vagy kiküszöbölése érdekében;

- felméri az állam készültségi szintjét a védelem biztosítása tekintetében, és ezzel összefüggésben jelentést nyújt be a köztársasági elnöknek és a parlament mindkét kamarájának a tényekről, valamint az állam védelmének megerősítésére irányuló javasolt intézkedésekről;

— jóváhagyja az állam védelmi stratégiáját; ${ }^{58}$

— dönt a fegyveres erők felépítésének, előkészítésének és felhasználásának alapvető irányairól, valamint a fegyveres erők mozgósításával kapcsolatos koncepcióról;

— jóváhagyja a polgári védelmi felkészítés koncepcióját;

- dönt az állam védelmének biztosításához szükséges egyéb, előre nem látható feladatokról;

- a köztársasági elnöknek és a parlamenti kamaráknak minden évben augusztus 31-ig (vagy kérelmükre bármikor) az állam védelméről szóló jelentést nyújt be. ${ }^{59}$

A törvény ugyanakkor nemcsak a kormány feladatait rögzíti, hanem meghatározza a többi minisztérium, az egyes régiók, az önkormányzatok, a közigazgatási szervek és a Cseh

54 Zákon č. 222/1999 Sb., o zajištování obrany České republiky (a továbbiakban: Védelmi tv.).

55 A két törvény tárgyi hatálya kapcsán lásd:Védelmi tv. 1. \$; Válságkezelési tv. 1. § (1) bekezdés.

56 Védelmi tv. 4 . $\$$.

57 A taxatív felsorolás kapcsán lásd:Védelmi tv. 5. \$(1) bekezdés a)-k) pont.

58 A cseh Védelmi Minisztérium honlapján elérhető a legfrissebb, 2017-ben elfogadott védelmi stratégia: www. army.cz/en/ministry-of-defence/strategy-and-doctrine/defence-strategy-of-the-czech-republic-135549/ (Letöltve: 2020 . december 15.).

59 Védelmi tv. 5. $\$$ (3) bekezdés. 
Nemzeti Bank feladatait is a különleges jogrendre való felkészülés tekintetében. ${ }^{\circ}{ }^{\circ}$ Kiemelendő, hogy a törvény egészét áthatja az állami és önkormányzati szervek között fennálló együttmúködési és adatközlési kötelezettség - ezáltal is elősegítve a különleges jogrendre való felkészülést célzó intézkedések gyorsabb és hatékonyabb megvalósítását.

A Válságkezelési tv. szintén a kormány szerepének elsődlegességét hangsúlyozza a különleges jogrendre való felkészülés tekintetében. E törvény azonban nem szabályozza különálló módon azt, hogy a kormánynak békeidőben, valamint ettől elkülönülten, a különleges jogrend elrendelése esetén milyen ellátandó feladatai vannak, hanem e két kategóriát összevonja a szabályozás során. A Válságkezelési tv. által a kormány hatáskörébe utalt feladatok ${ }^{61}$ funkciójukat tekintve alapvetően megegyeznek a Védelmi tv.-ben rögzített kormányzati hatáskörökkel - értelemszerúen fegyveres erőkkel kapcsolatos rendelkezések a Válságkezelési tv.-ben nem kerültek rögzítésre. Új elemként jelenik meg ugyanakkor, hogy a kormány:

- feladatokat ruház(hat) a válságkezelő hatóságokra, valamint irányítja és ellenőrzi is e hatóságok tevékenységét; ${ }^{62}$

— jogosult valamely minisztériumot vagy más központi közigazgatási szervet kijelölni egy adott válsághelyzet megoldására való felkészülés összehangolására; ${ }^{63}$

- a válsághelyzetre való felkészülés során megvitatja a Cseh Nemzeti Bankkal a jegybank hatáskörébe tartozó intézkedéseket. ${ }^{64}$

A Cseh Köztársaság minisztériumainak és egyéb központi államigazgatási szerveinek létrehozásáról szóló, többször módosított 2/1969. törvény ${ }^{65}$ taxatív módon felsorolja az egyes minisztériumokhoz tartozó szakpolitikai területeket, és e területekhez kapcsolódóan meghatározza a különleges jogrendre való felkészülés során ellátandó feladatok körét. A téma szempontjából releváns rendelkezéseket - a már korábban rögzített, Védelmi Minisztériumra vonatkozó rendelkezéseken túl - csupán a Belügyminisztérium kapcsán találunk. A törvény rögzíti, hogy a Belügyminisztérium köteles ellátni a válságkezeléssel, a polgári vészhelyzeti tervezéssel, a lakosságvédelemmel, valamint az integrált mentőrendszerrel

60 Megjegyzendő, hogy a törvény a különleges jogrendre való felkészüléssel kapcsolatban a kormány mellett a védelmi minisztérium meghatározó szerepét emeli ki. A védelmi minisztérium által ellátandó feladatokról, azok taxatív felsorolásáról lásd: Védelmi tv. 6. \$ (1) bekezdés a)-i) pont. Megjegyzendő továbbá, hogy a Cseh Köztársaság minisztériumainak és egyéb központi államigazgatási szerveinek létrehozásáról szóló 2/1969. törvény taxatív módon meghatározza az egyes minisztériumok által ellátandó főbb feladatokat. E törvény a védelmi minisztérium feladatkörébe tulajdonképpen a Védelmi tv.-ben rögzítettekkel megegyező feladatokat utalja a különleges jogrendre való felkészülés tekintetében. Vö. az utóbbi törvény vonatkozó szakaszait az előbbi törvény 16. $\$$ (2) bekezdés a)-h) pontjával.

61 Válságkezelési tv. 4. \$.

62 Válságkezelési tv. 4. $\$$ (1) bekezdés a) pont.

63 Válságkezelési tv. 4. \$(1) bekezdés b) pont.

64 Válságkezelési tv. 4. $\$(2)$ bekezdés.

65 Zákon č. 2/1969 Sb., o zřízení ministerstev a jiných ústředních orgánů státní správy České republiky (a továbbiakban: Minisztériumi tv.). 
kapcsolatos feladatokat. ${ }^{66} \mathrm{Az}$ egyes minisztériumoknak a különleges jogrendre való felkészülésben betöltött szerepéről, békeidőben ellátandó feladataikról a már hivatkozott Védelmi tv., valamint a Válságkezelési tv. mellett az integrált mentőrendszerről szóló 239/2000. törvény ${ }^{67}$ rendelkezik. Figyelemmel ugyanakkor a terjedelmi korlátokra, jelen munkában nincs mód a vonatkozó jogszabályi rendelkezések bővebb ismertetésére.

A cseh szabályozás kapcsán elsőként az rögzítendő, hogy a válsághelyzet kategóriájába mely tényállások, élethelyzetek, fenyegetések sorolandók, hiszen ez alapján tudjuk a válságkezeléssel kapcsolatos jogi szabályozás kereteit meghatározni. A Válságkezelési tv. alapján a válsághelyzet egy gyưjitőfogalom, amely különböző rendkívüli események összességét jelöli. E törvény - a Mentőrendszer tv.-nyel összhangban - ilyen rendkívüli eseményként határozza meg egyrészről a klasszikus értelemben vett különleges jogrendi tényállásokat (így a hadiállapotot, az államot fenyegetố állapotot, valamint a szükségállapotot), másrészről pedig a kritikus infrastruktúra megzavarását eredményező rendkívüli eseményeket. ${ }^{68} \mathrm{~A}$ Válságkezelési tv. tárgyi hatálya ugyanakkor kizárólag azokra a rendkívüli eseményekre, helyzetekre terjed ki, amelyek nem kapcsolódnak az ország külső támadásokkal szembeni védelmének biztosításához. ${ }^{69}$ A gyakorlatban mindez tehát azt jelenti, hogy a hadiállapottal és az államot fenyegetô állapottal kapcsolatos, az ilyen válsághelyzetek kezelésére vonatkozó szabályozás más törvény hatálya alá tartozik..$^{70}$ Mindezek alapján megállapítható, hogy a cseh jogi szabályozásban a válsághelyzetről és a válságkezelésről tágabb és szúkebb értelemben is beszélhetünk. Míg a tágabb értelmezés szerint a válsághelyzet kategóriája magába foglalja a különleges jogrendi esetköröket is, addig a szúkebb értelmezés alapján e kategóriába csak a különleges jogrendi tényállásokon kívül eső rendkívüli események tartoznak.

A válságkezeléssel kapcsolatos alapvető szabályok a már hivatkozott Válságkezelési tv.-ben kerültek rögzítésre. E törvény meghatározza, hogy a kormányt, a minisztériumokat, az egyes régiókat, az önkormányzatokat, a közigazgatási szerveket és a Cseh Nemzeti Bankot a válságkezelés során milyen jogok illetik meg és milyen kötelezettségek terhelik. A törvény elsődlegesen a kormány hatáskörébe utalja a válságkezeléssel összefüggő feladatok ellátását. Ez alapján a kormány által ellátandó legfontosabb feladatok a válságkezeléssel kapcsolatban a következők:

- feladatokat ruház(hat) a válságkezelő hatóságokra, valamint irányítja és ellenőrzi is e hatóságok válságkezeléssel kapcsolatos tevékenységét, ${ }^{71}$ ugyanakkor a törvény garanciális szabályként azt is rögzíti, hogy a válságkezelő hatóságok a válságkezelés

66 Minisztériumi tv. 12. \$(1) bekezdés m) pont.

67 Zákon č. 239/2000 Sb., o integrovaném záchranném systému a o změně některých zákonů (a továbbiakban: Mentőrendszer tv.).

68 Válságkezelési tv. 2 . \$ b) pont.

69 Válságkezelési tv. 1. $\$$ (1) bekezdés.

70 A hadiállapottal és az államot fenyegető állapottal kapcsolatos részletszabályokat az Állambiztonsági alk.tv., valamint a Védelmi tv. tartalmazza.

71 Válságkezelési tv. 4. \$ (1) bekezdés a) pont. 
során úgy kötelesek eljárni, hogy a személyek jogaiba történő beavatkozás ne haladja meg a szükséges mértéket; ${ }^{72}$

— jogosult valamely minisztériumot vagy más központi közigazgatási szervet kijelölni egy adott válsághelyzet megoldására való felkészülés összehangolására; ${ }^{73}$

— dönt a válsághelyzetek kezelésére szolgáló kormányzati munkacsoport, a Központi Válságstáb (Ústřední krizový štáb) felállításáról; ${ }^{74}$

- a válsághelyzetre való felkészülés során megvitatja a Cseh Nemzeti Bankkal a jegybank hatáskörébe tartozó intézkedéseket.75

A törvény rögzíti továbbá, hogy a válsághelyzetre történő felkészülés és a válságkezelés során a cseh jegybank köteles válságkezelő személyzetet felállítani, valamint a lehetséges kockázati forrásokról áttekintést készíteni, kockázatelemzéseket végezni, valamint kiküszöbölni azokat a hiányosságokat, amelyek válsághelyzethez vezethetnek. ${ }^{76} \mathrm{~A}$ Válságkezelési tv. a kormány mellett a minisztériumok meghatározó szerepét emeli ki a válságkezelés tekintetében, azonban a terjedelmi korlátokra tekintettel jelen munkában nincs lehetőség az ezzel kapcsolatos részletszabályok ismertetésére.

Fentebb már ismertetésre került, hogy a kormány a válsághelyzetek kezelése céljából felállíthatja a kormányzati munkacsoportként múködő Központi Válságstábot. ${ }^{77} \mathrm{~A}$ Központi Válságstáb a kormány nemzetbiztonsági és védelmi kérdésekkel foglalkozó testülete, az NBT szervezeti struktúrájába tagozódik, annak egyik szervezeti egységeként múködik. A Központi Válságstáb a szükségállapot, az államot fenyegető állapot, a hadiállapot esetén, valamint Csehország biztonságát más módon veszélyeztetô válsághelyzetben a miniszterelnök döntése alapján áll fel, és elsődleges feladata, hogy megoldási javaslatokat nyújtson be a válsághelyzet megoldására az NBT-nek vagy adott esetben közvetlenül a kormánynak. ${ }^{78} \mathrm{~A}$ Központi Válságstáb feladat- és hatáskörébe tartozik továbbá, hogy a válságkezelés tekintetében összehangolja az egyes minisztériumok és más központi közigazgatási szervek tevékenységét, valamint hogy biztosítsa az operatív együttmúködést a különböző nemzetközi szervezetek válságkezelô testületeivel. ${ }^{79} \mathrm{~A}$ testület 17 fóből áll, élén a miniszterelnök által kinevezett személlyel. Főszabályként a testület munkáját a belügyminiszter vezeti, azonban az államot fenyegető állapot, hadiállapot, valamint egyéb, az ország biztonságát veszélyeztető külső támadás esetén a Központi Válságstáb vezetője a védelmi miniszter lesz. ${ }^{80}$

72 Válságkezelési tv. 39c. \$.

73 Válságkezelési tv. 4. \$(1) bekezdés b) pont.

74 Válságkezelési tv. 4. \$ (1) bekezdés c) pont, valamint 24a. \$.

75 Válságkezelési tv. 4. $\$$ (2) bekezdés.

76 Válságkezelési tv. 13. \$(1) bekezdés a)-b) pont.

77 A Központi Válságstáb múködésével kapcsolatos részletszabályokat a testület alapokmánya rögzíti, amelyet az 1500/2008. kormányhatározat (Usnesení vlády ČR ze dne 24. listopadu 2008 č. 1500) tartalmaz.

78 Központi Válságstáb alapokmány 2. cikk 1. és 2. pont, valamint a 3. cikk.

79 Központi Válságstáb alapokmány 2. cikk 4. pont a) alpont.

80 Központi Válságstáb alapokmány 4. cikk. (1)-(2) bekezdés. 


\section{Az alapjogok korlátozására vonatkozó szabályok különleges jogrend idején}

A cseh alkotmány értelmében az alapvető jogok és szabadságok a bírói hatalom védelme alatt állnak, ${ }^{81}$ ezáltal a cseh jogrendszer a legmagasabb szintű védelmet garantálja az alapjogok érvényesülésének. E téma kapcsán a cseh alkotmányos rend részét képező Alapjogok és Alapvető Szabadságok Chartája ${ }^{82}$ bizonyul kulcsfontosságú jogforrásnak, hiszen abban kerülnek rögzítésre az alapjogok és alapvető szabadságok korlátozása esetén alkalmazandó általános szabályok. ${ }^{83}$ A charta deklarálja, hogy kötelezettségeket kizárólag törvény állapíthat meg, és e kötelezettségek csak az alapvető jogok és szabadságok tiszteletben tartása mellett rendelhetők el. ${ }^{84}$ Fontos kitételként jelenik meg továbbá, hogy az alapjogok korlátozására kizárólag az Alapjogok és Alapvető Szabadságok Chartájával összhangban kerülhet sor, valamint, hogy az alapjogok korlátainak meghatározásakor meg kell őrizni azok lényeges elemét, illetve a korlátozások nem használhatók fel más célok érdekében, mint amelyeket törvény meghatározott. ${ }^{85}$

A fentiekhez kapcsolódik, hogy több szakirodalmi álláspont ${ }^{86}$ alapján egy demokratikus jogállamban bármely rendkívüli intézkedés bevezetéséhez több feltétel együttes fennállása szükséges. Az általunk vizsgált szakirodalmi álláspont kapcsán a következők emelendők ki: kivételesség, törvényesség, arányosság, célzottság, az alkotmányos rend alapjainak sérthetetlensége, az ellenőrzési mechanizmusok megléte, illetve a nemzetközi jogból eredő kötelezettségek tiszteletben tartása. ${ }^{87}$

A különleges jogrendi esetköröket szabályozó Állambiztonsági alk.tv. az alapjogok korlátozása kapcsán rendkívül szûkszavú, hiszen csak a szükségállapot kapcsán rögzít rendelkezéseket. Ahogy az már fentebb rögzítésre került, a szükségállapot elrendeléséről a kormány dönt. Az Állambiztonsági alk.tv. szabályozása alapján a szükségállapot kihirdetésével egyidejûleg a kormány köteles meghatározni, hogy az egyes, külön törvényben lefektetett alapjogok milyen mértékben kerülnek korlátozásra. Mindemellett a kormány feladata annak meghatározása is, hogy az egyes szervek vagy személyek tekintetében milyen típusú, illetve mértékű kötelezettséget ír elő.

Az alapjogok különleges jogrend idején történő korlátozása kapcsán a legfontosabb jogszabálynak a Válságkezelési tv. tekinthető, amely részletesen taglalja az elrendelhető intézkedések egyes kategóriáit. Kiemelendő azonban, hogy a jogszabály kifejezetten csak a szükség-

81 Alkotmány 4. cikk.

82 A téma kapcsán lásd bővebben: Husseini et al., 2020.

83 Stejskal, 2017, 47. o.

84 Alapjogok és Alapvető Szabadságok Chartája 4. cikk (1) bekezdés.

85 Alapjogok és Alapvető Szabadságok Chartája 4. cikk (2) és (4) bekezdés. E kapcsán lásd bővebben: Orava, 2015, 54. 0.

86 Dienstbier, 2016, 26-30. o.; Klíma, 2012; Ramraj-Guruswamy, 2011, 91-95. o.; Scheppele, 2010, 178. o.

87 Dienstbier-Derka-Horák, 2020, 421. o. 
állapot, illetve az államot fenyegetô állapot ideje alatt bevezethető korlátozó intézkedéseket szabályozza. Ezen a ponton fontosnak tartjuk rögzíteni azt a tényt is, hogy a Válságkezelési tv. második, a Válságkezelő szervek címet viselő fejezetén belül nemcsak a kormány, hanem más szervek hatásköreit is szabályozza, különös tekintettel a Belügyminisztériumra, az Egészségügyi Minisztériumra, a Közlekedésügyi Minisztériumra, az Ipari és Kereskedelmi Minisztériumra, a községekre, a városokra, a kiterjesztett hatáskörú önkormányzatokra, valamint a Cseh Nemzeti Bankra. Mindemellett a Válságkezelési tv.-ben az NBT és a Központi Válságstáb hatáskörei is szabályozásra kerülnek. Tekintettel jelen munka terjedelmi korlátaira, e ponton nem kerül sor az összes válságkezelő szerv tevékenységének ismertetésére, csupán a kormány által elrendelhető legfontosabb intézkedéseket mutatjuk be az alapjog-korlátozással összefüggésben.

A törvényből kitưnik, hogy szükségállapot és az államot fenyegető állapot idején a szükséges időre és a szükséges mértékben kizárólag az alábbi alapjogok korlátozhatók:

- a személyi sérthetetlenséghez és a magánlakás sérthetetlenségéhez füződő jog;

- a természetes és jogi személyek tulajdonhoz való joga és a használati jogok;

- a szabad mozgáshoz és a lakhatáshoz való jog (a veszélyeztetett vagy a válsághelyzet által érintett területek tekintetében);

- a gyülekezési jog (a veszélyeztetett vagy a válsághelyzet által érintett területek tekintetében);

— az üzleti tevékenység végzéséhez való jog (olyan tevékenységekkel összefüggésben, amelyek veszélyeztethetik vagy megzavarhatják, esetleg ellehetetlenítenék a válságintézkedések hatékony végrehajtását);

- a sztrájkhoz való jog (amennyiben a sztrájkjog gyakorlása a mentési és likvidációs munkálatok megszakításához vagy ellehetetlenítéséhez vezetne). ${ }^{88}$

A törvényben taxatív módon felsorolásra kerültek a kormány által a szükségállapot ideje alatt elrendelhetô intézkedések is. Ebbe a kategóriába tartoznak különösen a következő korlátozó intézkedések: a személyek, illetve a vagyon meghatározott területről történő evakuálása; a személyek meghatározott területekre történő belépésének, tartózkodásának és mozgásának tilalma; a munkakötelezettség elrendelése ${ }^{89} \mathrm{~A}$ kormány a szükségállapot ideje alatt jogosult intézkedéseket hozni az államhatárok védelme, valamint a külföldiek vagy a hontalan személyek tartózkodásának biztosítása érdekében, illetve ezzel összefüggésben a válságintézkedések végrehajtásának biztosítása miatt elrendelheti a katonaság bevetését is. Ezenfelül a kormány a szükségállapot fennállásának ideje alatt tilalmakat vezethet be a pénzeszközök kezelése, valamint a fizetési forgalom tekintetében. ${ }^{90}$

88 Válságkezelési tv. 5 . \$.

89 Válságkezelési tv. 6. $\$$ (1) bekezdés.

90 Válságkezelési tv. 6. \$(3) bekezdés. 
A Válságkezelési tv. külön szakaszban rögzíti az államot fenyegető állapot különleges jogrendi tényállásának ideje alatt elrendelhető intézkedések körét. Ezek részben olyan intézkedések, amelyek a szükségállapot ideje alatt is elrendelhetők, ${ }^{91}$ azonban a törvény kiemeli, hogy a már említett intézkedések mellett a kormány az államot fenyegetó állapot idején korlátozhatja a Cseh Köztársaság területére történő beutazást olyan személyek vonatkozásában, akik más ország állampolgárai, emellett pedig korlátozhatja a lőfegyverek és looszerek birtoklását és viselését, valamint fokozottan ellenőrizheti a tárolt lőfegyverek, lőszerek, robbanóanyagok, nukleáris anyagok, ionizáló sugárforrások, veszélyes vegyi anyagok, biológiai anyagok és a géntechnológiával módosított organizmusok forgalmát. ${ }^{92}$

\section{A különleges jogrend kihirdetésének gyakorlati esetei}

A fent rögzített különleges jogrendi tényállások közül Csehországban a szükségállapot kihirdetésére találunk gyakorlati példákat, míg az államot fenyegető állapot, valamint a hadiállapot³ kihirdetésére ez idáig nem került sor. A gyakorlati példák körén belül azonban el kell különítenünk egymástól azokat az eseteket, amikor a szükségállapotot az ország egész területére, illetve annak csak egy meghatározott részére rendelték el.

Elsőként - a teljesség igénye nélkül - a szükségállapot kihirdetésének utóbbi kategóriába tartozó esetköreit emeljük ki:

A 2002. augusztusi áradások következtében az ország több régiójában árvízválság alakult ki, amely az érintett régiókban élő emberek életét, testi épségét és vagyonbiztonságát jelentős mértékben veszélyeztette, így Vladimír Špidla miniszterelnök 5 régióra kiterjedő szükségállapotot hirdetett ki. ${ }^{94}$

A 2006. áprilisi áradások következtében az ország több régiójában árvízválság alakult ki, amely az érintett régiókban élő emberek életét, testi épségét és vagyonbiztonságát jelentős mértékben veszélyeztette, így a kormány 7 régióra kiterjedő szükségállapotot hirdetett ki. 95

91 A Válságkezelési tv. ezen a ponton kifejezetten utal a szükségállapot idején elrendelhető intézkedésekre, melyeket a 6. \$ (1) és (3) bekezdésében, valamint a 7. \$-ban rögzít.

92 Lásd erről bővebben a Válságkezelési tv. 7. \$-át.

$93 \mathrm{Az}$ 1918-ben létrejött, majd 1993-ban Csehországra és Szlovákiára kettévált Csehszlovákia történetében egyetlen alkalommal, a második világháború során került sor formálisan hadiállapot kihirdetésére. 1941-ben Edvard Beneš, emigrációba vonult csehszlovák államelnök kijelentette, hogy Csehszlovákia hadban áll a náci Németországgal, valamint Magyarországgal, mivel e két ország megsértette a csehszlovák állam szuverenitását.

94 Rozhodnutí Předsedy vlády č. 373/2002 Sb. (373/2002. számú miniszterelnöki határozat). A szükségállapot 2002. augusztus 12 -től augusztus 22 -ig tartott.

95 Rozhodnutí vlády č. 121/2006 Sb. (121/2006. számú kormányhatározat). A szükségállapot 2006. április 2-tól április 19-ig tartott. 
A 2007. januári hurrikán következtében az ország több régiójában olyan súlyos válsághelyzet alakult ki, amely az ott élő emberek életét, testi épségét és vagyonbiztonságát jelentôs mértékben veszélyeztette, így a kormány szükségállapotot hirdetett ki. ${ }^{96}$

A 2013. júniusi áradások következtében az ország több régiójában árvízválság alakult ki, amely az érintett régiókban élő emberek életét, testi épségét és vagyonbiztonságát jelentős mértékben veszélyeztette, így a kormány 6 régióra és a fơvárosra, Prágára kiterjedő szükségállapotot hirdetett ki.97

A hivatkozott esetek kapcsán láthatjuk, hogy szükségállapot elrendelésére kivétel nélkül természeti katasztrófa eredményeként elóálló válsághelyzet miatt került sor, amely válsághelyzet az érintett régiókban élő emberek életét, testi épségét és vagyonbiztonságát jelentős mértékben veszélyeztette. A szükségállapotot kihirdető kormány-, illetve miniszterelnöki határozatokban minden esetben rögzítésre kerül, hogy a válsághelyzettel összefüggésben mely alapjog milyen mértékben kerül korlátozásra. Így azt látjuk, hogy például a tulajdonhoz való jog a válsághelyzet kezeléséhez szükséges mértékben korlátozásra került; a szabad mozgás és tartózkodás joga, illetve a gyülekezési jog a veszélyeztetett vagy a válsághelyzet által érintett területeken korlátozásra került; a vállalkozáshoz, illetve az üzleti tevékenység végzéséhez fưződő jog szintén korlátozásra került, amennyiben e jog gyakorlója tevékenysége során veszélyeztette, megzavarta vagy megakadályozta a válságintézkedések végrehajtását. A szükségállapot kihirdetésével kapcsolatos közjogi vita vagy ehhez kapcsolódó bírósági ítélet és alkotmánybírósági döntés nem ismert a példaként hozott esetek vonatkozásában.

A modern kori Csehország történetében először 2020-ban, a koronavírus-járvánnyal összefüggésben került bevezetésre a szükségállapot az ország egész területére..$^{98} \mathrm{~A}$ koronavírus-járvány kezdeti szakaszában a cseh egészségügyi miniszter rendkívüli intézkedések (mimořádné opatření) bevezetése mellett döntött, amire a közegészség védelméről szóló 258/2000. törvény (a továbbiakban: Közeü.tv.) hatalmazta fel. ${ }^{99} \mathrm{~A}$ rendkívüli intézkedések bevezetését követően, 2020. március 12-én - egy nappal a veszélyhelyzet magyarországi elrendelését követően - a kormány a különleges jogrend bevezetését tartotta szükségesnek, ezért szükségállapotot hirdetett az ország egész területére. ${ }^{100} \mathrm{Az}$ Állambiztonsági alk.tv. értelmében - ahogy azt már fentebb is említettük - szükségállapot elrendelésére akkor van lehetőség, ha természeti, ökológiai vagy ipari katasztrófa következett be, vagy más olyan esemény, amely

96 Rozhodnutí vlády č. 11/2007 Sb. (11/2007. számú kormányhatározat). A szükségállapot 2007. január 25-től február 5 -ig tartott.

97 Rozhodnutí vlády č. 140/2013 Sb. (140/2013. számú kormányhatározat). A szükségállapot 2013. június 2-tól június 28-ig tartott.

98 Hojnyák-Ungvári, 2020, 125-128. o.

99 A törvény 80 . \$ (1) bekezdés g) pontja hatalmazza fel az egészségügyi minisztert a sürgősségi intézkedések megalkotására járványhelyzet idején, míg a 69. \$ (1) bekezdés nevesíti azokat az intézkedéstípusokat, amelyek járvány vagy annak bekövetkezésének veszélye esetén kerülhetnek elrendelésre.

100 Sova, 2020, 298. o. 
az életet, az egészséget, a vagyonbiztonságot, a közrendet vagy a közbiztonságot jelentős mértékben veszélyezteti. A szükségállapot során az állam a jogi eszközök három típusát alkalmazta a járvány kockázatának és következményeinek kezelésére: a törvényeket, a kormányzati válságintézkedéseket (amelyek kormányhatározatok formájában realizálódtak), valamint az egészségügyi miniszter által kibocsátott rendkívüli intézkedéseket.

Csehországban a szükségállapot elrendelése rendkívüli felhatalmazást biztosított a kormány számára a koronavírus-járvány kezeléséhez szükséges gyors és hatékony intézkedések meghozatalára, illetve az alapjogok korlátozására. ${ }^{101} \mathrm{Az}$ alapjogok korlátozása kapcsán elsődlegesen a Válságkezelési $\mathrm{tv}^{102}$ bír relevanciával, hiszen e jogszabály rögzíti, hogy a kormány - mint a rendeleti kormányzás felhatalmazottja - mely alapjogokat és milyen mértékben, illetve feltételek szerint jogosult korlátozni szükségállapot idején. A járvány jellegéből adódik, hogy a rendkívüli helyzet megfelelő kezelése érdekében Csehországban különösen az alábbi alapjogok kerültek korlátozásra: a szabad mozgáshoz való jog, a tartózkodási hely szabad megválasztásának joga, a gyülekezési jog, az oktatáshoz való jog, illetve a vállalkozás szabadsága. ${ }^{103}$

A szükségállapotot a különleges jogrendi állapotot szabályozó Állambiztonsági alk. tv. által megengedett leghosszabb időtartamra, 30 napra rendelték el. A szükségállapot végül - annak kétszeri meghosszabbítását követően - 66 nap után, 2020. május 17-én ért véget, a fokozott higiéniai és egészségügyi elóirások betartása azonban az elkövetkezendő időszakra is kötelező volt. A koronavírus-járvány második hullámát a szakértők októberre jósolták, azonban az a vártnál jóval korábban érkezett, és arra késztette a cseh kormányt, hogy ismét szükségállapotot hirdessen. A szükségállapot kihirdetésére 2020. október 5-én került sor, amely eredetileg 2020. november 3-ig volt érvényben, ugyanakkor a képviselőház e kézirat lezárásának időpontjáig három alkalommal, először november 20-ig, másodszor december 12-ig, legutóbb pedig december 23-ig meghosszabbította azt, tekintettel arra, hogy a kormány által hozott intézkedések érvényben tartása - a romló egészségügyi helyzet miatt - továbbra is indokolt.

E ponton szólni kívánunk azokról a közjogi-politikai vitákról is, amelyek a szükségállapot országos szintű kihirdetésével összefüggésben jelentkeztek. A szükségállapot kihirdetésével összefüggésben számos olyan, jogilag releváns eset vált ismertté, amely a cseh kormányzat feltételezett alkotmányellenes, valamint a jogállamiság kritériumait sértő intézkedéseit állította középpontba. Olyan alkotmányjogi panaszok és a közigazgatási bíróságokhoz benyújtott keresetek váltak ismertté a különleges jogrend bevezetésével összefüggésben, amelyek a kormány intézkedéseinek megsemmisítésére irányultak. E keresetek és alkotmányjogi panaszok elsősorban arra hivatkoznak, hogy a szükségállapot elrendelésére alkotmányellenes módon került sor, vagy hogy a kormány által a szükségállapottal összefüg-

101 Venice Commission, 2020, IV.D. 55. és 58. pont.

$102 \mathrm{Az}$ alapjogok korlátozása kapcsán e törvény 5 . \$a)-e) pontja, valamint a 6. \$ és 7. \$ bír kiemelt jelentőséggel. 103 A téma kapcsán lásd bővebben: Syllová, 2020, 19-21. 0. 
gésben kibocsátott jogszabályok alapjog-korlátozásra vonatkozó rendelkezései több esetben nem összeegyeztethetők a szükségesség-arányosság kritériumaival, illetve nem állnak összhangban az alkotmánytörvényben, valamint a Válságkezelési tv.-ben foglalt, alapjog-korlátozásra vonatkozó rendelkezésekkel. ${ }^{104} \mathrm{E}$ közjogi-politikai viták közül jelen munkában az alábbi konkrét eseteket kívánjuk röviden bemutatni.

David Zahumenský cseh ügyvéd 2020. március 26-án alkotmányos panaszt nyújtott be a cseh alkotmánybírósághoz. Panaszának jogalapját azzal indokolta, hogy véleménye szerint a szükségállapot kihirdetésére nem az alkotmányos renddel összhangban került sor, a szükségállapot kihirdetése nem tartja tiszteletben az alapvető emberi jogok védelmének követelményeit, továbbá kifogásolta a kormány egyes válságintézkedéseit, valamint az egészségügyi miniszter által kibocsátott intézkedéseket is, és kérte azok megsemmisítését. Az alkotmánybíróság a panaszt azonban több okból kifolyólag is elutasította: ${ }^{105}$

- a szükségállapot kihirdetéséről szóló kormányhatározat tekintetében azért, mert az alkotmánybíróság nem rendelkezik hatáskörrel annak alkotmányossága megítélése tekintetében;

- az egyes válságintézkedések kapcsán azért, mert a panaszt nyilvánvalóan nem az arra jogosult személy nyújtotta be;

- az egészségügyi miniszter intézkedései tekintetében pedig azért, mert a miniszter egyes intézkedéseit korábban már hatályon kívül helyezték.

Ezt követően Zahumenskýék az Emberi Jogok Európai Bíróságához fordultak jogorvoslatért.

Zahumenský felesége, Vendula Zahumenská a férje képviseletében még az alkotmányos panasz benyújtása előtti napokban, 2020. március 17-én egy keresettel ${ }^{106}$ fordult a Prágai Városi Bírósághoz, amelyben az egészségügyi miniszter által kibocsátott néhány intézkedést, a kormány egyes válságintézkedéseit, valamint a szükségállapot kihirdetésérôl szóló kormányhatározatot kifogásolta, és kérte azok megsemmisítését. A bíróság a keresetet április 28-án elutasította. Ennek következtében Zahumenský és felesége panasszal fordultak a Legfelsőbb Közigazgatási Bírósághoz, kérelmezve a Prágai Városi Bíróság határozatának megsemmisítését. Kérelmüket a Legfelsőbb Közigazgatási Bíróság is elutasította. ${ }^{107}$

2020. április 23-án helyezte hatályon kívül a Prágai Városi Bíróság a cseh egészségügyi miniszternek a koronavírus-járvánnyal összefüggésben meghozott négy sürgősségi intézkedését, amelyek korlátozták az állampolgárok szabad mozgását, valamint üzleti-gazdasági tevékenységük végzését. ${ }^{108} \mathrm{~A}$ bíróság szerint az intézkedések törvényellenesek voltak, mert

104 Hojnyák-Ungvári, 2020, 134-136. o.

105 Például ÚS 8/20 sz. határozat.

106 Ügyiratszáma: 10 A 35/2020.

1072 As 141/2020 sz. ítélet.

108 Hejč, 2020, 185. o. 
meghozatalukra egy miniszternek sincs jogosultsága, ilyen döntéseket csak a kormány hozhat a Válságkezelési tv. alapján. ${ }^{109}$

Az alkotmánybíróság a koronavírus-járvány második hulláma alatt, novemberben, formai okokra hivatkozva két másik alkotmányos panaszt ${ }^{110}$ is elutasított, amelyeket a szükségállapot bevezetése és a korlátozó intézkedések kihirdetése miatt nyújtottak be. Az alkotmánybíróság hivatalos honlapján található tájékoztatás alapján a panaszokat nem az arra jogosult személyek nyújtották be, ezért kerültek elutasításra. ${ }^{111}$

\section{4. Összegzés}

Az alábbi táblázatban összefoglaljuk a cseh különleges jogrendi szabályozással kapcsolatos legfontosabb rendelkezéseket:

\begin{tabular}{|c|c|c|c|c|}
\hline & Szükségállapot & \begin{tabular}{|c} 
Közvetlen \\
veszélyhelyzet
\end{tabular} & $\begin{array}{c}\text { Államot fenyegető } \\
\text { állapot }\end{array}$ & Hadiállapot \\
\hline $\begin{array}{l}\text { Szabályozás } \\
\text { szintje }\end{array}$ & \multicolumn{3}{|c|}{ Alkotmányos (alkotmánytörvény) } & $\begin{array}{l}\text { Alkotmányos } \\
\text { (alkotmány és } \\
\text { alkotmánytörvény) }\end{array}$ \\
\hline Elrendelési okok & \multicolumn{2}{|c|}{$\begin{array}{l}\text { — Természeti, ökológiai, ipari } \\
\text { katasztrófa; } \\
\text { — más olyan esemény, amely } \\
\text { az életet, a vagyonbiztonságot, } \\
\text { a közrendet vagy a közbiz- } \\
\text { tonságot jelentős mértékben } \\
\text { veszélyezteti. }\end{array}$} & $\begin{array}{l}\text { Külső hatalom } \\
\text { az állam szuvere- } \\
\text { nitását, területi } \\
\text { integritását vagy } \\
\text { demokratikus } \\
\text { alapjait közvet- } \\
\text { lenül fenyegeti. }\end{array}$ & $\begin{array}{l}\text { — A Cseh Köz- } \\
\text { társaságot } \\
\text { megtámadják; } \\
\text { — nemzetközi } \\
\text { szerződés közös } \\
\text { védelmi kötele- } \\
\text { zettséget ír elő. } \\
\end{array}$ \\
\hline Elrendelés & $\begin{array}{l}\text { A kormány, } \\
\text { azonban a képvi- } \\
\text { selőház hatályon } \\
\text { kívül helyezheti. }\end{array}$ & $\begin{array}{l}\text { A miniszter- } \\
\text { elnök, de } 24 \\
\text { órán belül } \\
\text { a kormánynak } \\
\text { jóvá kell } \\
\text { hagynia, } \\
\text { azonban } \\
\text { a képviselőház } \\
\text { e döntést is } \\
\text { hatályon kívül } \\
\text { helyezheti. }\end{array}$ & $\begin{array}{l}\text { A kormány indít- } \\
\text { ványára a törvény- } \\
\text { hozás két házának } \\
\text { (képviselőház és } \\
\text { szenátus) abszolút } \\
\text { többsége. }\end{array}$ & $\begin{array}{l}\text { A törvényhozás két } \\
\text { házának (képvi- } \\
\text { selőház és szenátus) } \\
\text { abszolút többsége. }\end{array}$ \\
\hline
\end{tabular}

109 A téma kapcsán lásd bővebben: Rủžička, 2020, 549. o.

110 Például ÚS 99/20 és ÚS 100/20 sz. határozatok.

111 E kapcsán lásd a cseh alkotmánybíróság hivatalos honlapján szereplő közleményt: www.usoud.cz/aktualne/ ustavni-soud-odmitl-dve-stiznosti-proti-usnesenim-vlady-o-vyhlaseni-nouzoveho-stavu-a-o-prijetikrizoveho-opatreni (Letöltve: 2020. december 15.). 


\begin{tabular}{|c|c|c|c|c|}
\hline Felhatalmazott & Koükségállapot & $\begin{array}{c}\text { Közvetlen } \\
\text { veszélyhelyzet }\end{array}$ & $\begin{array}{c}\text { Államot fenyegetón } \\
\text { állapot }\end{array}$ & Hadiállapot \\
\hline Gyakorlati esetek & $\begin{array}{c}\text { Kormány, Nemzeti Biztonsági } \\
\text { Tanács }\end{array}$ & $\begin{array}{c}\text { Nem tartalmaz } \\
\text { bóvebbendelkezést. } \\
\text { lönleges jogrend kihirl } \\
\text { detésének gyakorlati } \\
\text { esetei címú részt. }\end{array}$ & Ez idáig nem került kihirdetésre. \\
\hline $\begin{array}{c}\text { Különleges jog- } \\
\text { rendnek nem } \\
\text { minősülő rend- } \\
\text { kívüli helyzet }\end{array}$ & \multicolumn{3}{|c|}{ Veszélyhelyzet (a Válságkezelési tv. alapján) } \\
\hline
\end{tabular}

\section{5. táblázat}

A Cseh Köztársaság különleges jogrendi szabályainak összegzése Forrás: a szerzők sajátösszeállítása

A különleges jogrendre vonatkozó alapvető szabályok a cseh jogrendben alkotmányos szinten, a Cseh Köztársaság Alkotmányában, valamint az Állambiztonsági alk.tv.-ben találhatók meg. A cseh szabályozás a különleges jogrendi esetkörök között három kategóriát nevesít: a szükségállapotot, az államot fenyegető állapotot, valamint a hadiállapotot, azonban külön rögzítendő a közvetlen veszélyhelyzet kategóriája, amely a szükségállapot egy speciális, gyorsított eljárási formájának tekinthető. Az egyes kategóriák kapcsán a cseh szabályozás korrekt módon rögzíti az elrendelésükre okot adó fenyegetéseket és élethelyzeteket. A klasszikus értelemben vett különleges jogrendi esetkörök mellett a cseh jogi szabályozásban megjelenik a veszélyhelyzet kategóriája is, amelyet egyes szakirodalmi források a különleges jogrendi esetkörök negyedik típusaként tartanak számon. A Válságkezelési tv. által nevesített veszélyhelyzet olyan esetkörként jelenik meg a cseh szabályozásban, amely elrendelése esetén - a törvény által az állami és önkormányzati szervek számára biztosított jogosítványoknál fogva - alkalmas lehet egy rendkívüli esemény következtében előálló válsághelyzet kezelésére, ilyenformán pedig szoros kapcsolatot mutat a különleges jogrendi tényállásokkal.

Az elvégzett kutatásból kitúnik, hogy a különleges jogrendi esetkörök elrendelése kapcsán a törvényhozó hatalom dominanciája érvényesül a cseh szabályozásban, hiszen az államot fenyegetó állapotot és a hadiállapotot a parlament rendeli el, míg a szükségállapot és a közvetlen veszélyhelyzet esetében a parlament utólagosan megsemmisítheti a kormánynak vagy a miniszterelnöknek a különleges jogrend elrendelésére vonatkozó döntését. A rendeleti kormányzás felhatalmazottja szükségállapot, valamint az államot fenyegető állapot esetén a kormány, azonban az utóbbi különleges jogrendi kategória esetében - mintegy 
döntés-elókészítő szervként - megjelenik az NBT is. Az NBT - amely a kormány állandó munkacsoportjaként mûkködik - a miniszterelnökből és a kormány által megbízott miniszterekből áll, és e szerv legfőbb feladata a kormány által meghatározott mindazon javaslat elkészítése, amely az állam védelme érdekében szükséges. A hadiállapot tekintetében azonban a cseh szabályozás hiányossága figyelhető meg, hiszen sem az alkotmány, sem pedig az alkotmánytörvény nem rögzíti, hogy ki vagy mely állami szerv van felhatalmazva a rendeleti kormányzásra. A különleges jogrendi tényállások vonatkozásában a köztársasági elnök szerepe neutrális, jogosítványai korlátozottak.

A különleges jogrendet megelőző, az arra való felkészülést szolgáló békeidejû szabályok ugyan több törvényben kerültek rögzítésre, azonban e törvények egymással szoros kapcsolatban állnak, és funkcionálisan kiegészítik egymást. E törvények a kormány, valamint a Védelmi Minisztérium meghatározó szerepét emelik ki a különleges jogrendre való felkészüléssel kapcsolatban. Ez a szabályozási megoldás mindenképpen hordozhat magában előnyöket, hiszen végső soron gyorsabbá és hatékonyabbá teheti a különleges jogrendre való felkészülés folyamatát. Kiemelendő, hogy e törvényekben nemcsak a kormány és a minisztériumok feladatai kerültek rögzítésre, hanem az egyes régiók, az önkormányzatok, a közigazgatási szervek és a Cseh Nemzeti Bank feladatai is meghatározásra kerültek.

A cseh alkotmányos szabályozás nem tartalmaz kifejezett rendelkezéseket a válságkezeléssel kapcsolatban, ide nem értve ugyanakkor a különleges jogrendre vonatkozó alkotmányos szabályokat. A válságkezeléssel kapcsolatos legfontosabb szabályok egy jogszabályban, a Válságkezelési tv.-ben kerültek rögzítésre. A válsághelyzetek gyors és hatékony kezeléséhez, a veszély elhárításához nagymértékben hozzájárulhat az, ha a válságkezeléssel kapcsolatos szabályok egységesen, egy jogszabályban kerülnek rögzítésre - e tekintetben pedig a cseh jogi szabályozás jó példaként szolgál. A Válságkezelési tv. meghatározza, hogy az egyes állami és önkormányzati szerveket milyen jogok illetik meg és milyen kötelezettségek terhelik a válságkezelés során. A téma szempontjából lényeges, hogy a kormány a válsághelyzetek kezelése céljából felállíthatja a kormányzati munkacsoportként múködő Központi Válságstábot, amely a kormány nemzetbiztonsági és védelmi kérdésekkel foglalkozó testülete, az NBT szervezeti struktúrájába tagozódik, annak egyik szervezeti egységeként múködik. A Központi Válságstáb különleges jogrend idején, valamint Csehország biztonságát más módon veszélyeztető válsághelyzetben a miniszterelnök döntése alapján áll fel, és elsődleges feladata, hogy megoldási javaslatokat nyújtson be az NBT-nek vagy adott esetben közvetlenül a kormánynak a válsághelyzet megoldására.

$\mathrm{Az}$ alapjogok különleges jogrend idején történő korlátozása kapcsán megjegyzendő, hogy arra kizárólag a cseh alkotmányos rend részét képező Alapjogok és Alapvető Szabadságok Chartájával összhangban kerülhet sor, amely jogszabály rögzíti az alapjogok korlátozásának általános szabályait. Az alapjog-korlátozás tekintetében részletesebb szabályokat határoz meg a Válságkezelési tv., amely ugyanakkor konkrétan csak két különleges jogrendi 
esetkör, a szükségállapot, valamint az államot fenyegető állapot vonatkozásában rögzíti a korlátozható alapjogok körét, illetve a korlátozás formáját és mértékét.

Ami a különleges jogrend kihirdetésének gyakorlati eseteit illeti, megállapítható, hogy az államot fenyegető állapot, valamint hadiállapot elrendelésére ez idáig nem került sor, azonban a szükségállapot kihirdetésére számos példát találunk. E gyakorlati példák közül kétségtelenül a koronavírus-járvány miatt a közelmúltban két alkalommal is kihirdetett országos szintû szükségállapot tekinthető a legjelentősebbnek. A különleges jogrend bevezetése kapcsán közjogi-politikai jellegú viták is értelemszerúen ezzel kapcsolatban merültek fel a közelmúltban.

A cseh és a magyar szabályozás összevetése kapcsán elsőként rögzítendő, hogy mindkét nemzeti szabályozás alkotmányos szinten rögzíti a különleges jogrenddel kapcsolatos legfontosabb szabályokat. Míg Csehországban a különleges jogrendi esetkörök hármas felosztása érvényesül (szükségállapot, államot fenyegető állapot, hadiállapot), addig a hatályos magyar szabályozás hat különleges jogrendi kategóriát nevesít (rendkívüli állapot, szükségállapot, megelőző védelmi helyzet, terrorveszélyhelyzet, váratlan támadás, veszélyhelyzet). E ponton fontosnak tartjuk rögzíteni, hogy az Alaptörvény kilencedik módosítása ${ }^{112}$ jelentôsen átalakította a különleges jogrendre vonatkozó hazai szabályozást. A 2023. július 1-jén hatályba lépő változások következtében a korábbi hat különleges jogrendi kategóriát három váltja fel: a hadiállapot, a szükségállapot, valamint a veszélyhelyzet. Ilyenformán a magyar szabályozás - a cseh szabályozáshoz hasonlóan - a különleges jogrendi esetkörök hármas felosztását veszi át. A változások eredményeképpen a cseh és a magyar különleges jogrendi esetkörök tartalmilag is közelíteni fognak egymáshoz: a magyar veszélyhelyzet kategóriája a cseh szükségállapot kategóriájával, a magyar szükségállapot kategóriája pedig a cseh államot fenyegető állapottal mutat hasonlóságot, míg a háborús szituációhoz kapcsolódó rendkívüli helyzetek mind a cseh, mind a magyar jogrendben a hadiállapot kategóriája alatt kerülnek szabályozásra. További lényeges változás, hogy az Alaptörvény módosítása nyomán különleges jogrend idején a Kormány szerepe és felelőssége jelentősen megnő, hiszen mindhárom különleges jogrendi helyzet vonatkozásában a Kormány lesz a rendeleti kormányzás felhatalmazottja, mindez pedig szintén hasonlóságot mutat a hatályos cseh szabályozással. A különleges jogrendre való felkészülést segítô, valamint a válságkezelésre vonatkozó szabályozást illetően megállapítható, hogy míg Csehországban kifejezetten e kérdésekkel foglalkozó dedikált jogszabályok, addig Magyarországon különböző tárgyú - elsősorban honvédelemmel, valamint katasztrófavédelemmel foglalkozó - jogszabályok rendezik e területek jogi szabályozását.

Közös vonás, hogy a különleges jogrend kihirdetését követően a kormány meghatározó szerepe érvényesül, továbbá mindkét ország esetében elmondható, hogy a köztársasági elnök

112 Magyarország Alaptörvényének kilencedik módosításáról szóló T/13647. számú törvényjavaslat. Az Alaptörvény módosításáról szóló törvényt a kézirat lezárásáig nem hirdették ki a Magyar Közlönyben. 
szerepe többnyire neutrális, az államfők jogosítványai korlátozottak különleges jogrend idején. Habár a rendeleti kormányzás felhatalmazottja mindkét ország esetében a kormány, azonban mindez nem jelenti a törvényhozó hatalom teljes kiiktatását, hiszen a nemzeti parlamenteknek széles körủ jogosítványai vannak mind Csehországban, mind pedig Magyarországon a különleges jogrend kihirdetése, meghosszabbítása, valamint megszüntetése tekintetében. Megjegyzendő továbbá, hogy a - 2023. július 1-jétől megszúnő - magyar Honvédelmi Tanácshoz hasonló, rendkívüli állapotban az államfö, a parlament és a kormány szerepét is átvevő testületre nincs példa a cseh jogi szabályozásban, ugyanakkor az NBT - mint a cseh kormány nemzetbiztonsági és védelmi kérdésekkel foglalkozó testülete - funkcióját tekintve több elemében is hasonlóságot mutat a magyar jogintézménnyel. Habár a két testület összetétele és hatásköre különböző, de tevékenységük megegyezik a tekintetben, hogy a védelmi-nemzetbiztonsági koordinációban kiemelt szerepet játszanak különleges jogrend idején.

A cseh szabályozáshoz hasonlóan a magyar szabályozás is alkotmányos szinten rendelkezik az alapjog-korlátozás legfontosabb szabályairól. Az Alaptörvény is rögzít úgynevezett általános alapjog-korlátozási klauzulát [I. cikk (3) bekezdés], valamint számos alapvető jog esetén kifejezetten utal a korlátozás lehetőségére. Míg a cseh alkotmányos szabályozás rendkívül szúkszavú az alapjogok különleges jogrend idején történő korlátozásával kapcsolatban, addig az Alaptörvény rögzíti, hogy különleges jogrend idején az általános szabályozáshoz képest szélesebb körben van lehetőség az alapjogok korlátozására. A cseh és a magyar nemzeti szabályozás közös vonása továbbá az is, hogy a különleges jogrend során elrendelhető alapjog-korlátozás részletszabályai törvényi szinten kerültek rögzítésre. Míg Csehországban e tekintetben a Válságkezelési tv. tekinthető a legfontosabb jogszabálynak, addig Magyarországon - az úgynevezett honvédelmi tárgyú különleges jogrendi kategóriák esetén - a honvédelemről és a Magyar Honvédségről, valamint a különleges jogrendben bevezethető intézkedésekről szóló 2011. évi CXIII. törvény, valamint - a veszélyhelyzeti kategória vonatkozásában - a katasztrófavédelemről és a hozzá kapcsolódó egyes törvények módosításáról szóló 2011. évi CXXVIII. törvény.

Ahogyan az a fentebbi elemzésből is kitúnik, a meglehetősen túlszabályozott, struktúráját és fogalomrendszerét tekintve olykor nehezen átlátható és értelmezhető hatályos magyar szabályozáshoz képest a cseh különleges jogrendi szabályozás letisztultabb képet mutat. A cseh szabályozás korrekt módon rögzíti az egyes különleges jogrendi kategóriák elrendelésére okot adó fenyegetéseket, nem hagyva kétséget afelól, hogy az adott helyzetben melyik tényállás elrendelése szükséges és kívánatos. Ezt a megállapítást erôsíti az a tény is, hogy a különleges jogrendi tényállások tekintetében - a fennálló fenyegetés, veszély intenzitása alapján - a fokozatosság elve tisztán érvényesül. Megjegyzendő ugyanakkor, hogy pozitív elemei ellenére a cseh különleges jogrendi szabályok számos ponton hiányosak, elég, ha csak a hadiállapottal kapcsolatos, korábban már rögzített hiányosságokra gondolunk. 


\section{Irodalomjegyzék}

Belling, V. (2018) 'Výjimečný stav a hranice právního státu', Právník, 157(3), 200-220. o.

Dienstbier, J. (2016) 'Mimořádne situace a stavy v ústavní historii' in Wintr, J., Antoš, M. (szerk.) Vybrané problémyústavního práva v historické perspektivě. 1. kiadás. Praha: Univerzita Karlova, Právnická fakulta

Dienstbier, J., DeRKA, V., HorÁk, F. (2020) 'Ústavnost mimořádných opatření podle zákona o ochraně veřejného zdraví', Právník, 159(5), 417-432. o.

FARKAS, Á., KELEMEN, R. (szerk.) (2020) Szkülla és Kharübdisz között-Tanulmányok a különleges jogrend elméleti és pragmatikus kérdéseiről, valamint nemzetközi megoldásairól. 1. kiadás. Budapest: Magyar Katonai Jogi és Hadijogi Társaság

HEJČ, D. (2020) 'Nezákonnost mimořádných opatření Ministerstva zdravotnictví k onemocnění COVID-19 podle MS v Praze: Když obsah překračuje formu', Soudní rozhledy, 26(6), 185-190. o.

HoJNYÁK, D., UngVÁRI, Á. (2020) 'Az Európai Unió egyes tagállamainak koronavírusjárványra adott válasza, különös tekintettel a vizsgált államok által bevezetett különleges jogrendi szabályozásra', Miskolci Jogi Szemle, 15(1), 122-138. o.

HusseInI, F. ET AL. (2020) Listina základních práva svobod. Komentářr. 1. kiadás. Praha: C. H. Beck Kelemen, R. (2019) 'Az Alaptörvény szülkségállapot-szabályozásának kritikai áttekintése az egyes európai uniós tagállamok alkotmányainak figyelembevételével - Különös tekintettel a visegrádi államok alkotmányaira' in Bartkó, R. (szerk.) A terrorizmus elleni küzdelem aktuális kérdései a XXI. században. 1. kiadás. Budapest: Gondolat Kiadó

Khakee, A. (2009) Securing Democracy? A Comparative Analysis of Emergency Powers in Europe. Genf: Geneva Centre for the Democratic Control of Armed Forces [Online]. Elérhető: www.files.ethz.ch/isn/99550/PP30_Anna_Khakee_Emergency_Powers.pdf (Letöltve: 2020. december 15.)

KLÍMA, K. ET AL. (2009) Komentářk Ústavěa Listině. 2. kiadás. Plzeň: Aleš Čeněk

KLíma, K. (2012) O právu ústavním. 1. kiadás. Praha: Wolters Kluwer

KUDRNA, J. (2017) 'Ústavní rámec zajištování bezpečnosti České republiky - zhodnocení současného stavu a úvahy de lege ferenda', Acta Universitatis Carolinae Iuridica, 63(4), 159174. 0 .

MAREš, M., NovÁK, D. (2019) Ústavní zákon o bezpečnosti České republiky (110/1998 Sb.). Komentář. 1. kiadás. Praha: Wolters Kluwer

Orava, V. (2015) Omezení základních práv při mimořádných situacích. 1. kiadás. Brno: Masarykova Univerzita, Právnická fakulta

Pavlíček, V., Gronský, J., Hřebejk, J., Jirásková, V., Mikule, V., PešKa, P., Sládeček, V., SUCHÁNEK, R., Syllová, J. (2011) Ústavní právo a státověda, II. díl. Ústavní právo České republiky. 1. kiadás. Praha: Leges

Ramraj, V. V., Guruswamy, M. (2011) 'Emergency Powers' in Ginsburg, T., Dixon, R. (szerk.) Comparative Constitutional Law. 1. kiadás. Cheltenham: Edward Elgar 
RŮŽIČKA, P. (2020) 'Právní režim nouzového stavu', Právní rozhledy, 28(15-16), 549-555. o.

Rychetský, P., LANGÁšEK, T., Herc, T., MLSNA, P., BARoš, J., JÄGER, P., MAJERČÍí, L', MATOUŠEK, L., Popovičová, L., Pospí̌̌ll, I., UHL, P. (2015) Ústava České republiky, Ústavní zákon o bezpečnosti ČR. Komentář. 1. kiadás. Praha: Wolters Kluwer

SCHEPPELE, K. L. (2010) 'Legal and Extralegal Emergencies' in Whittington, K. E., Kelemen, R. D., Caldeira, G. A. (szerk.) The Oxford Handbook of Law and Politics. 1. kiadás. Oxford: Oxford University Press

SLÁDEČEK, V. (2020) 'Vláda a nouzový stav', Správní právo, 53(5-6), 266-281. o.

Sova, A. (2020) 'Přezkum opatření přijatých v době nouzového stavu', Správní právo, 53(5-6), 298-312. 0.

Stejskal, J. (2017) Mimořádné stavy v právním řádu ČR. 1. kiadás. Praha: Univerzita Karlova, Právnická fakulta

SYllová, J. (2020) 'K vyhlášení nouzového stavu v březnu 2020, opatřením vlády ministerstva zdravotnictví', Parlamentní institut, 2020/12 [Online]. Elérhető: www.psp.cz/sqw/text/ orig2.sqw?idd=171939 (Letöltve: 2020 . december 15.)

VANíčEK, J. (2001) ‘Činnost ústavních orgánů za krizových situací', Správní právo, 34(5), 257278. 0.

VENICE COMMISSION (2020) Interim Report on the Measures Taken in the EU Member States as a Result of the COVID-19 Crisis and Their Impact on Democracy, the Rule of Law and Fundamental Rights (Study No. 995/2020) [Online]. Elérhető: www.venice.coe.int/webforms/documents/?pdf=CDL-AD(2020)018-e (Letöltve: 2020 . december 15.)

WinTR, J. (2020) 'K ústavnosti a zákonnosti protiepidemických opatření na jaře 2020', Správní právo, 53(5-6), 282-297. o. 